\title{
Factors affecting reproduction in red deer (Cervus elaphus) hinds on Rhum
}

\author{
F. E. Guinness, S. D. Albon and T. H. Clutton-Brock
}

King's College Research Centre, Cambridge CB2 IST, U.K.

\begin{abstract}
Summary. In a population of free-ranging red deer hinds on the Isle of Rhum (Inner Hebrides) we investigated relationships between four aspects of reproductive performance (fertility, calf birth weight, birth sex ratio and calving date) and four variables likely to affect the mother's condition: age, reproductive status, home range area and year of calving. Fertility was significantly related to mother's age, reproductive status and home range area as well as to year of calf's birth. Stag calves were heavier than hind calves and birth weight was significantly related to mother's age, home range area and year of (calf's) birth but not to mother's reproductive status. Birth sex ratio did not differ from parity, and was not significantly associated with any of the four variables examined. Birth date was significantly related to the mother's reproductive status, home range area and year of (calf's) birth but not to mother's age or the sex of the calf.
\end{abstract}

\section{Introduction}

Many studies of ungulates have shown that reproductive performance is related to the mother's reproductive condition or to factors which affect this (Sadleir, 1969; Caughley, 1977). Lower pregnancy rates, lower birth weights and later birth dates tend to occur in (1) old animals compared to young (Sadleir, 1969); (2) mothers that have reared one or more offspring the previous year compared to those which have not (Mitchell, McCowan \& Nicholson, 1976); (3) populations in which food supplies are sparse because the animals are living in marginal habitat or population density is high (Mitchell, Staines \& Welch, 1977; Staines, 1978); (4) years when food is short compared to those when it is abundant (McCullough, 1971). However, there has so far been little attempt to compare the importance of different factors or to examine the extent to which they interact. In the present study of red deer we considered four aspects of reproductive performance, the frequency of parturition (i.e. fertility), the sex of offspring, birth weight and birth date, and examined relationships between these and mother's age, mother's reproductive status in the previous year, home range area and calf's year of birth.

\section{Materials and Methods}

\section{Study area}

All data were collected on the North Block of the Isle of Rhum (Inner Hebrides) between 1971 and 1976. Both the study area and the island have been described elsewhere (Lowe, 1969: CluttonBrock \& Guinness, 1975). The study area was divided into four parts (see Text-fig. 1). (1) Upper Kilmory Glen $\left(3 \mathrm{~km}^{2}\right)$ extended from the mid-point of Kilmory Glen to the watershed at the southern end. (2) Lower Kilmory Glen $\left(2 \cdot 86 \mathrm{~km}^{2}\right)$ was the area from the mid-point of Kilmory Glen northwards to the sea and included the western face of Mullach Mor and the eastern face of Sgaorishal. (3) The Kilmory/Shamhnan Insir watershed (referred to as the Intermediate area, $1.96 \mathrm{~km}^{2}$ ) extended from the eastern edge of Kilmory Bay eastwards to the edge of Shamhnan Insir itself. (4) Shamhnan Insir $\left(1.35 \mathrm{~km}^{2}\right)$ extended from the immediate environs of the bay southwards to the top of Mullach Mor. 
Population density was highest at Shamhnan Insir $\left(18.5 \mathrm{hinds} / \mathrm{km}^{2}\right)$ and lowest in Upper Kilmory $\left(4 \cdot 3 / \mathrm{km}^{2}\right)$. Lower Kilmory and Shamhnan Insir included relatively large areas of Agrostis/Festuca and herb-rich grassland (Ferreira, 1970) which the animals strongly selected: $16.7 \%$ and $13.3 \%$ of their respective areas were covered by these vegetation types while comparative percentages for Upper Kilmory and the Intermediate area were 1.67 and 1.30 (figures calculated from Ferreira, 1970). The overall population density and the number of hinds/ha of grassland were higher at Shamhnan

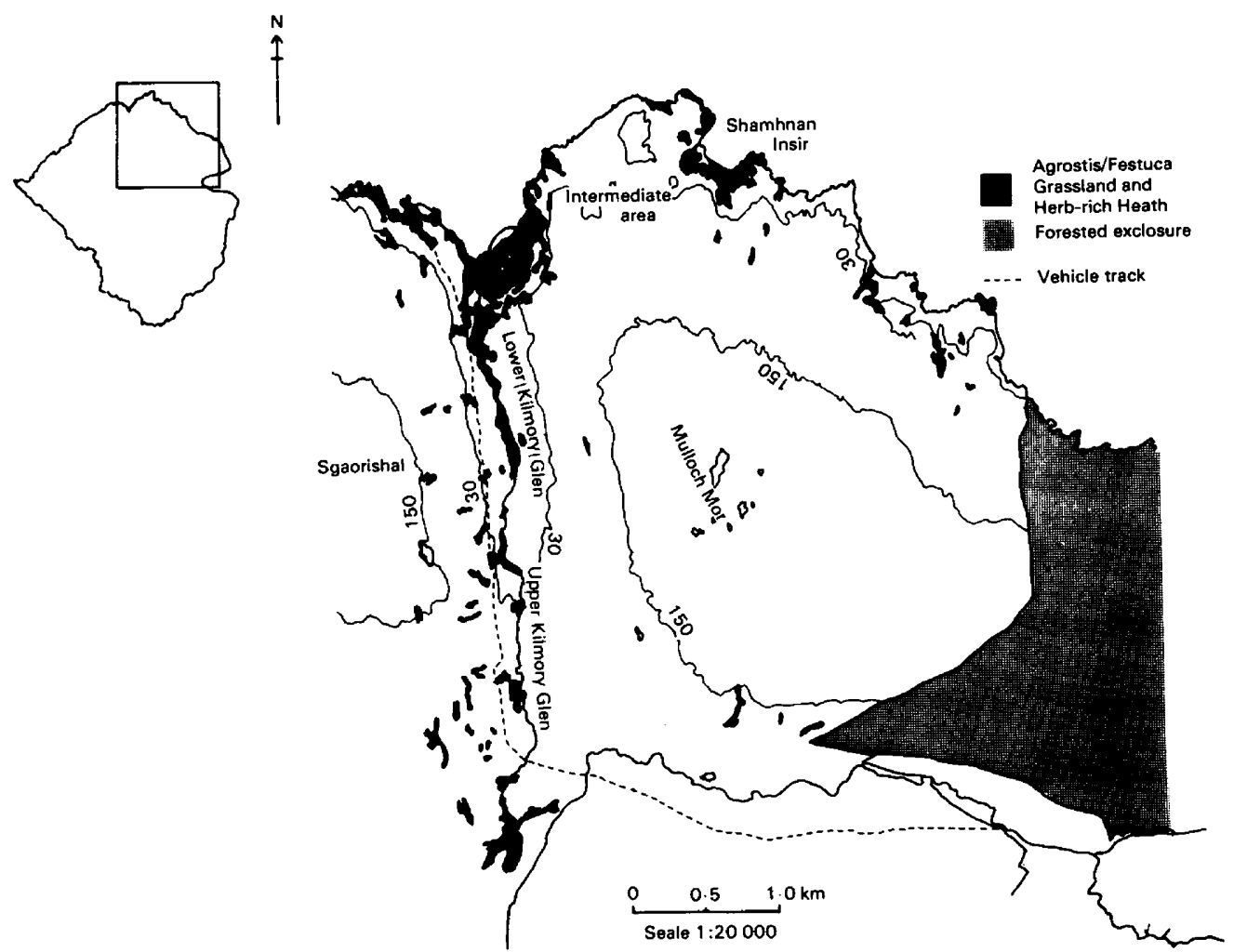

Text-fig. 1. Map of the study area on Rhum, showing the distribution of Agrostis-Festuca and herb-rich grasslands. Contour lines show height above sea level in metres.

Insir than Lower Kilmory. Circumstantial evidence suggests that food availability was lower at Shamhnan Insir: standing crop on the herb-rich grassland was generally lower in this area (T. H. Clutton-Brock, unpublished data) and winter calf mortality was higher (Guinness, Clutton-Brock \& Albon, 1978b).

\section{Animals}

The numbers of stags, hinds and calves which used the study area in each year (1971-1976) are shown in Table 1: figures were taken from census counts of the area which were repeated 5 times each month. Since 1974, the deer in the study area have not been culled; the stag population remained approximately constant while the hind population increased by 48 animals.

The following information was obtained.

Fertility, i.e. the proportion of hinds $\geqslant 3$ years of age which gave birth to calves. Whether or not a hind calved in a particular year was determined by close observation of individual hinds during the calving season (see below).

Age of dam. The ages of all hinds using the study area were known, to an accuracy of \pm 1 year for older animals, from maintaining recognition of them since they were yearlings, from fear $_{\mathrm{C}}$ tags used 
Table 1. The numbers (calculated at the end of April) of stags, hinds $\geqslant 1$-year-old and calves using the four parts of the study area in different years

\begin{tabular}{llrrrrr}
\hline Year & Deer & $\begin{array}{c}\text { Upper } \\
\text { Kilmory }\end{array}$ & $\begin{array}{c}\text { Lower } \\
\text { Kilmory }\end{array}$ & $\begin{array}{c}\text { Intermediate } \\
\text { area }\end{array}$ & $\begin{array}{c}\text { Shamhnan } \\
\text { Insir }\end{array}$ & Total \\
\hline \multirow{2}{*}{1972} & Stags & 26 & 65 & 5 & 18 & 114 \\
& Hinds & 8 & 19 & 18 & 14 & 59 \\
& Calves & 5 & 7 & 8 & 3 & 23 \\
\hline 1973 & Stags & 21 & 65 & 10 & 20 & 122 \\
& Hinds & 9 & 22 & 20 & 15 & 66 \\
& Calves & 6 & 12 & 10 & 8 & 36 \\
\hline 1974 & Stags & 30 & 67 & 13 & 17 & 127 \\
& Hinds & 8 & 26 & 17 & 18 & 69 \\
& Calves & 3 & 11 & 8 & 8 & 30 \\
\hline 1975 & Stags & 29 & 60 & 7 & 16 & 117 \\
& Hinds & 9 & 30 & 21 & 20 & 80 \\
& Calves & 5 & 16 & 6 & 6 & 33 \\
\hline \multirow{2}{*}{1976} & Stags & 25 & 68 & 7 & 10 & 110 \\
& Hinds & 11 & 35 & 28 & 22 & 96 \\
& Calves & 3 & 13 & 8 & 9 & 33 \\
\hline 1977 & Stags & 19 & 70 & 12 & 16 & 117 \\
& Hinds & 13 & 40 & 29 & 25 & 107 \\
& Calves & 6 & 14 & 9 & 7 & 36 \\
\hline
\end{tabular}

in a previous study or from tooth wear and other physical characteristics (see Guinness, Gibson \& Clutton-Brock, 1978a). The ages given in the text are those of the dam at the time of giving birth; e.g. an animal which became pregnant when she was a 2-year-old and calved the following June was recorded as a 3-year-old. This usage differs from that of Mitchell (1973) who measured fertility before calving and therefore classified animals according to the year in which they conceived. In analyses involving interactions between mother's age and other variables, the age categories have been grouped as 3-4 years, 5-7 years, $8-10$ years and $\geqslant 11$ years.

Status of dam in the year before the breeding season. Three classes of hinds were recognized: immature yeld (hinds which had never bred); yeld, i.e. 'true' yeld (mature hinds which had not given birth the previous year) and summer yeld (hinds which had bornea calf but hadlost it before theend of the first September); and milk, i.e. winter yelds (hinds which had borne a calf and lost it between October and May: the majority of such calves died between February and April) and 'true' milk (animals which had successfully reared a calf the previous year). The rationale for this classification was that true yeld and summer yeld hinds had not suffered the nutritional strain of rearing a calf through the winter whereas both winter yeld and milk hinds had done so.

Home range of dam. This was the part of the study area usually occupied by the mother (see above).

Date of birth of calf. Calving was associated with an increase in udder size (Guinness, Lincoln \& Short, 1971; Blaxter, Kay, Sharman, Cunningham \& Hamilton, 1974), with a reduction in body size and with a variety of behavioural changes (Clutton-Brock \& Guinness, 1975). As soon as these had been seen, we attempted to locate the hind and her calf. When the hind disappeared from her usual range and was later found with a calf we assumed that the birth had occurred on the day after she was last seen in her usual home range (see Clutton-Brock \& Guinness, 1975). For all years except 1973 the date of birth was assessed for $95 \%$ of calves. Hinds which were not pregnant were identified by body shape and absence of a distended udder (Guinness et al., 1971; Blaxter et al., 1975).

Weight of calf at birth. The calves were caught with a long handled net, weighed and marked with ear flashes and/or an expanding collar. For calves marked within $24 \mathrm{~h}$ of birth, the weight at marking 
was taken as the birth weight. For those marked $\leqslant 12$ days after calving, we assumed a weight gain of $0.40 \mathrm{~kg} /$ day (see Youngson, 1971; Mitchell, 1971) and extrapolated back to find the birth weight of the calf.

Year of birth of each calf. Because population density was rising (Table 1), inter-year differences were confounded with density changes. Where sample size was too small to examine differences between years, we have examined whether differences existed between the first half of the study (1971-1973) when population density was relatively low and the second half (1974-1976) when it had increased (see Table 1).

\section{Analyses}

Data were drawn from a total of 91 breeding hinds. Our sample of calves was too small to allow us to analyse individual relationships and births from different hinds have been considered together, assuming each birth to be a statistically independent event. Sample size was too small to permit multi-variate statistics involving more than three variables at a time. For normally distributed variables, analyses of variance were used and for skewed distributions the Kruskal-Wallis test (Siegel, 1956). For frequency data, we employed G tests (Sokal \& Rohlf, 1969) and used repeated tests to analyse relationships between three specific variables at a time. These tests were to show (i) whether two variables were significantly related or were statistically independent of each other, and (ii) whether two variables interacted in their effect on a third (see Sokal \& Rohlf, 1969). Throughout the text, the terms 'independence' and 'interaction' are used in their specialized, statistical sense. Although we quote percentage figures in conjunction with the results of $G$ tests in the text, tests were always carried out on frequencies.

\section{Results}

\section{Fertility}

Fertility varied with age, as found by Mitchell (1973) for a large sample of hinds collected from Rhum. No 2-year-old calved; 3-year-old hinds showed lower fertility than 4-year-olds $(G=5 \cdot 228$; d.f. $=1 ; P<0.05)$; 4-year-olds showed lower fertility than animals of 5-10 years $(\mathrm{G}=5.024$; d.f. $=1 ; P<0.05)$; and there was a non-significant trend to reduced fertility in hinds aged $>12$ years (Table 2).

Table 2. Mean percentage fertility among hinds allocated to eight age classes

\begin{tabular}{lllllllll}
\hline & \multicolumn{8}{c}{ Age (years) } \\
\cline { 2 - 8 } & $3-4$ & $5-6$ & $7-8$ & $9-10$ & $11-12$ & $13-14$ & $15-16$ & $17-18$ \\
\hline No. of hinds & 66 & 62 & 56 & 42 & 29 & 14 & 4 & 2 \\
$\%$ Fertility & $61 \cdot 7$ & $83 \cdot 7$ & $87 \cdot 5$ & 92.9 & 93.5 & 87.5 & $80 \cdot 0$ & 0 \\
\hline
\end{tabular}

As in previous studies of the red deer population of Rhum (Lowe, 1969; Mitchell, 1973), milk hinds showed lower fertility $(82.2 \%$ overall) than yelds $(95.5 \%$ overall $)(\mathrm{G}=8.42 ; \mathrm{d} . \mathrm{f} .=1 ; P<0.01)$. However, this difference was smaller than that found in two previous studies $(48.1 \%$ : Lowe, 1969 ; $55.6 \%$; Mitchell, 1973). This difference between the three studies was highly significant $(\mathrm{G}=42.72$; d.f. $=1 ; P<0.001 ; \mathrm{G}=16.07 ;$ d.f. $=1 ; P<0.001$ respectively), and was due to the lower fertility of the milk hinds studied by Lowe (1969) and Mitchell (1973). Although the data of Lowe (1969) and Mitchell (1973) were based on counts of corpora lutea, rather than of calves born as in the present study, twins are rare in red deer, suggesting that the difference in fertility between the studies was at least as great as these figures indicate.

In all years except 1973 there was a tendency for the proportion of yeld hinds to be higher among animals which had reared a male calf in the previous year $\left(7 \cdot 1-36: 4 \%\right.$ between years with mean of m $_{27 \mathrm{AM}}$ 
$22.9 \%)$ than in those which had reared a female calf $(0-26.7 \%$ with a mean of $13.4 \%)$. Differences in fertility between the two groups were significant (Wilcoxon Matched Pairs Signed Ranks Test; $\mathrm{T}=2 ; n=7 ; P<0.05$ ). There was no evidence of any interaction between mother's age and home range area or between mother's status and home range area and fertility (see Table 3). However, mother's status may interact with age: 4-year-old milk hinds were less likely $(61.5 \%)$ to be fertile than older animals $(95.7 \%)(\mathrm{G}=23.673$; d.f. $=1 ; P<0.001)$. Hinds using Kilmory were more fertile than the rest of the population $(\mathrm{G}=4.082$; d.f. $=1 ; P<0.05)$ and those using Shamhnan Insir were less fertile $(G=4 \cdot 123$, d.f. $=1, P<0.05$; see Table 4$)$. These differences were evidently not the product of inter-area differences in the ages of hinds (see Table 3 ) and could not have been produced by inter-area differences in reproductive status: although rather more yeld hinds occurred at Shamhnan Insir, the effect of this should be to enhance and not depress fertility (see above). The difference in fertility between Kilmory and Shamhnan Insir occurred because 3-4-year-olds at Shamhnan Insir tended to show low fertility: 4-year-old milk hinds were never observed to calve in Shamhnan Insir while 5-10-year-olds at Kilmory showed particularly high fertility. Despite the fact that area differences primarily affected young animals, there was no significant interaction between fertility, home range area and mother's age, or between fertility, mother's home range and mother's status.

Table 3. Comparisons (by 3-way G tests) for (a) fertility, dam's home-range area and dam's age and (b) fertility, dam's reproductive status and dam's home-range area

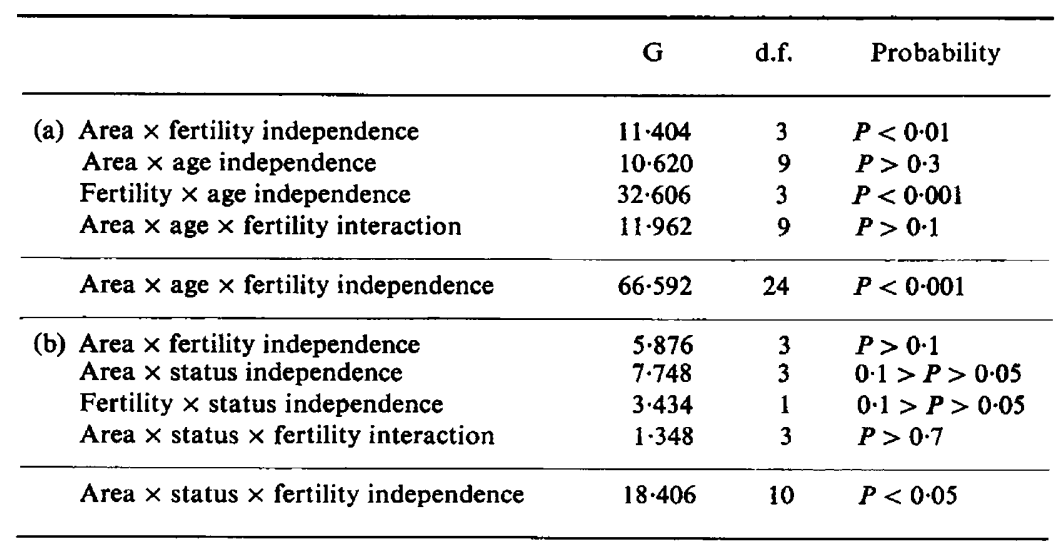

Table 4. Percentage fertility of deer (across years) in the four parts of the study area

\begin{tabular}{lcccc}
\hline & \multicolumn{3}{c}{ Area } & \\
\cline { 2 - 4 } & $\begin{array}{c}\text { Upper } \\
\text { Kilmory }\end{array}$ & Intermediate & $\begin{array}{c}\text { Lower } \\
\text { Kilmory }\end{array}$ & $\begin{array}{c}\text { Shamhnan } \\
\text { Insir }\end{array}$ \\
\hline $\begin{array}{l}\text { No. of hinds } \\
\% \text { Fertility (range) }\end{array}$ & $82(50-100)$ & $79 \cdot 5(66-82 \cdot 5)$ & $86 \cdot 3(71-100)$ & $73 \cdot 7(45 \cdot 5-88 \cdot 5)$ \\
\hline
\end{tabular}

The overall proportion of adult hinds calving varied between years from 72 to $92 \%(\mathrm{G}=15 \cdot 332$; d.f. $=5 ; P<0.01)$, being $72 \%$ in $1971(\mathrm{~N}=41), 92 \%$ in $1972(\mathrm{~N}=51), 80 \%$ in $1973(\mathrm{~N}=56), 92 \%$ in $1974(\mathrm{~N}=62), 72 \%$ in $1975(\mathrm{~N}=67)$ and $78 \%$ in $1976(\mathrm{~N}=80)$. These changes were evidently not the product of differences in either age distribution or reproductive status, and were not correlated with changes in population density. 
Sex of calf

Sex ratio was slightly biased towards males in the population as a whole, although the trend was not significant: of a total of 254 calves born between 1971 and 1976 whose sex was identified, 138 $(54.3 \%)$ were males $(G=1.902$; d.f. $=1 ; P>0.1)$. None of the factors examined had a significant effect on calf sex ratio (Table 5) and there was no evidence that interactions between variables obscured variation in the sex ratio. Contrary to traditional belief, there was no significant tendency for yeld hinds to produce male calves.

\section{Calf weight}

The weights of calves were similar to those obtained by Lowe (cited by Mitchell, 1971) from the island as a whole; and were $6.90 \mathrm{~kg}(6.76 \mathrm{~kg}$ : Mitchell, 1971) for stag calves and $6.44 \mathrm{~kg}(6.35 \mathrm{~kg}$ : Mitchell, 1971) for hind calves. Differences in calf weight between the sexes were just significant $(t=2.064$; d.f. $=167 ; P<0.05$ ).

Birth weights of calves differed significantly according to the age category of the dam (Table 6: $F=15.585 ;$ d.f. $=5,163 ; P<0.001$ ). Mean calf weight increased with mother's age from first breeding to a peak in animals of $9-10$ and subsequently declined.

Table 5. Birth sex ratio in different groups of red deer calves

\begin{tabular}{|c|c|c|c|}
\hline & \multicolumn{2}{|c|}{ Calves } & \multirow[b]{2}{*}{$\%$ males } \\
\hline & Males & Females & \\
\hline \multicolumn{4}{|c|}{ Age of mother (years) } \\
\hline 3 & 13 & 13 & $50 \cdot 0$ \\
\hline 4 & 17 & 15 & $53 \cdot 1$ \\
\hline $5-7$ & 49 & 40 & $55 \cdot 1$ \\
\hline $8-10$ & 35 & 29 & $54 \cdot 7$ \\
\hline $11+$ & 24 & 19 & 55.8 \\
\hline \multicolumn{4}{|c|}{ Reproductive status of mother } \\
\hline First breeders & 21 & 18 & $55 \cdot 3$ \\
\hline Yeld & 34 & 28 & $54 \cdot 8$ \\
\hline Milk & 78 & 63 & 53.8 \\
\hline \multicolumn{4}{|c|}{ Dam's home range area } \\
\hline Upper Glen & 19 & 18 & $51 \cdot 4$ \\
\hline Kilmory & 47 & 42 & $52 \cdot 8$ \\
\hline Intermediate & 36 & 24 & $60 \cdot 0$ \\
\hline Shamhnan Insir & 26 & 27 & $49 \cdot 1$ \\
\hline \multicolumn{4}{|l|}{ Year } \\
\hline 1971 & 15 & 10 & $60 \cdot 0$ \\
\hline 1972 & 24 & 15 & 61.5 \\
\hline $1973^{*}$ & 13 & 17 & $43 \cdot 3$ \\
\hline 1974 & 27 & 25 & 51.9 \\
\hline 1975 & 26 & 23 & $53 \cdot 1$ \\
\hline 1976 & 30 & 26 & 53.6 \\
\hline
\end{tabular}

* These figures may be biased because some calves were sexed at the age of 11 months.

There was no significant difference in birth weight between the offspring of milk and yeld hinds in the overall sample $(t=0.443$; d.f. $=137 ; P>0.5)$, or from the median birth weights in each year (Kilmogorov-Smirnov 2-sample test, $D=0.13 ; n_{1}=79 ; n_{2}=33 ; P>0.1$ ). The importance of this result is that it indicates that any differences in calf mortality between the offspring of milk and yeld hinds (Guiness et al., 1978b) are unlikely to be a product of differences in calf weight.

Birth weight differed significantly between hinds using different parts of the study area 
Table 6. Birth weight in calves born to hinds of different ages

\begin{tabular}{|c|c|c|c|c|c|c|}
\hline & \multicolumn{6}{|c|}{ Age (years) } \\
\hline & $3-4$ & $5-6$ & $7-8$ & $9-10$ & $11-12$ & $13+$ \\
\hline $\begin{array}{l}\text { No. of hinds } \\
\text { Birth weight (tg) }\end{array}$ & 42 & 35 & 37 & 25 & 19 & 14 \\
\hline $\begin{array}{l}\text { Mean } \\
\text { Range }\end{array}$ & $\begin{array}{c}6 \cdot 35 \\
3.04-8 \cdot 89\end{array}$ & $\begin{array}{c}6 \cdot 72 \\
2 \cdot 68-9 \cdot 16\end{array}$ & $\begin{array}{c}7 \cdot 04 \\
4 \cdot 72-10 \cdot 16\end{array}$ & $\begin{array}{c}7 \cdot 32 \\
2 \cdot 54-11 \cdot 16\end{array}$ & $\begin{array}{c}6 \cdot 33 \\
4 \cdot 08-8 \cdot 57\end{array}$ & $\begin{array}{c}6.08 \\
4 \cdot 08-7 \cdot 71\end{array}$ \\
\hline
\end{tabular}

$(\mathrm{F}=5.04$; d.f. $=3,168 ; P<0.005)$ : in Upper and Lower Kilmory the calves weighed $7.47 \pm 1.32 \mathrm{~kg}$ $(\mathrm{N}=16)$ and $7.01 \pm 1.65 \mathrm{~kg}(\mathrm{~N}=72)$ respectively and in Shamhnan Insir and the Intermediate area they were $6.48 \pm 1.02 \mathrm{~kg}(\mathrm{~N}=38)$, and $6.28 \pm 1.39 \mathrm{~kg}(\mathrm{~N}=45)$, respectively.

Birth weight showed no significant relationship with date of birth. Calculation of the medians and interquartile ranges of birth dates for each year showed that birth weight did not differ significantly between quartiles either in the whole sample or in any particular year $(\mathrm{F}=1 \cdot 247$; d.f. $=3,165, P>$ 0.25 ), although there was a tendency for calves born in the first and last quartiles to be heaviest. Birth weight (mean \pm s.d.) apparently differed between years, being $6.67 \pm 1.27 \mathrm{~kg}(\mathrm{~N}=15)$ in 1971 , $6.73 \pm 1.36 \mathrm{~kg}(\mathrm{~N}=20)$ in $1972,7 \cdot 16 \pm 1.68 \mathrm{~kg}(\mathrm{~N}=36)$ in $1974,6.39 \pm 1.36 \mathrm{~kg}(\mathrm{~N}=40)$ in 1975 , and $6.70 \pm 1.45 \mathrm{~kg}(\mathrm{~N}=52)$ in 1976 , the sample size was too small to show overall significant differences $(F=1.253$; d.f. $=5,158 ; P>0.25)$. There was no evidence that population density interacted with mother's age, reproductive status, home range area or birth dates to affect birth weight.

\section{Date of birth}

Date of birth was not significantly related to the sex of the calf or to the mother's age, although there was a tendency for old hinds ( $\geqslant 11$ years) to calve later than prime animals ( $5-10$ years) $(\mathrm{G}=$ 4.18; d.f. $=1 ; P<0.05$ ). Hinds using different parts of the study area varied significantly in their dates of calving ( $G=8.86$; d.f. $=3 ; P<0.05$ : see Text-fig. 2 ), those using Lower Kilmory Glen calving earliest.

\section{Discussion}

Perhaps the most important outcome of the study was the demonstration that, within a population, the dam's home range area had an important effect on most aspects of reproductive performance, being related to fertility (especially among young animals), birth weight (especially in the offspring of yeld hinds), birth date and calf mortality (see Guinness et al., 1978b). As expected, Lower Kilmory hinds, with a relative abundance of good grazing, showed high fertility, high birth weights and early birth dates. In contrast, Shamhnan Insir animals showed comparatively low fertility, late calving and low birth weights. Hinds using the Intermediate area resembled those using Lower Kilmory in birth date and those using Shamhnan Insir in birth weight. If variation in reproductive success exists within red deer populations because of differences in resource access, it is likely that increasing population density will affect the various categories of individuals differentially and have important consequences for the process of population regulation (Lomnicki, 1978).

Although most of our results were similar to those of previous studies of the Rhum population (Lowe, 1969; Mitchell, 1971, 1973; Mitchell \& Lincoln, 1973; Mitchell et al., 1976), some differences were obtained. For example, our estimates of the number of milk hinds calving were considerably higher than those found by Lowe (1969) and Mitchell (1973), although data from several other Highland deer forests (Mitchell, 1973) give figures as high as ours. Also, the fertility of the older milk hinds was higher in the present study than in that of Lowe (1969): in milk hinds $\geqslant 11$ years of age 51 out of $56(91.1 \%)$ calved in the present study compared with 5 out of $12(42.5 \%)(\mathrm{G}=7 \cdot 42$; d.f. $=$ $1 ; P<0.01)$. 

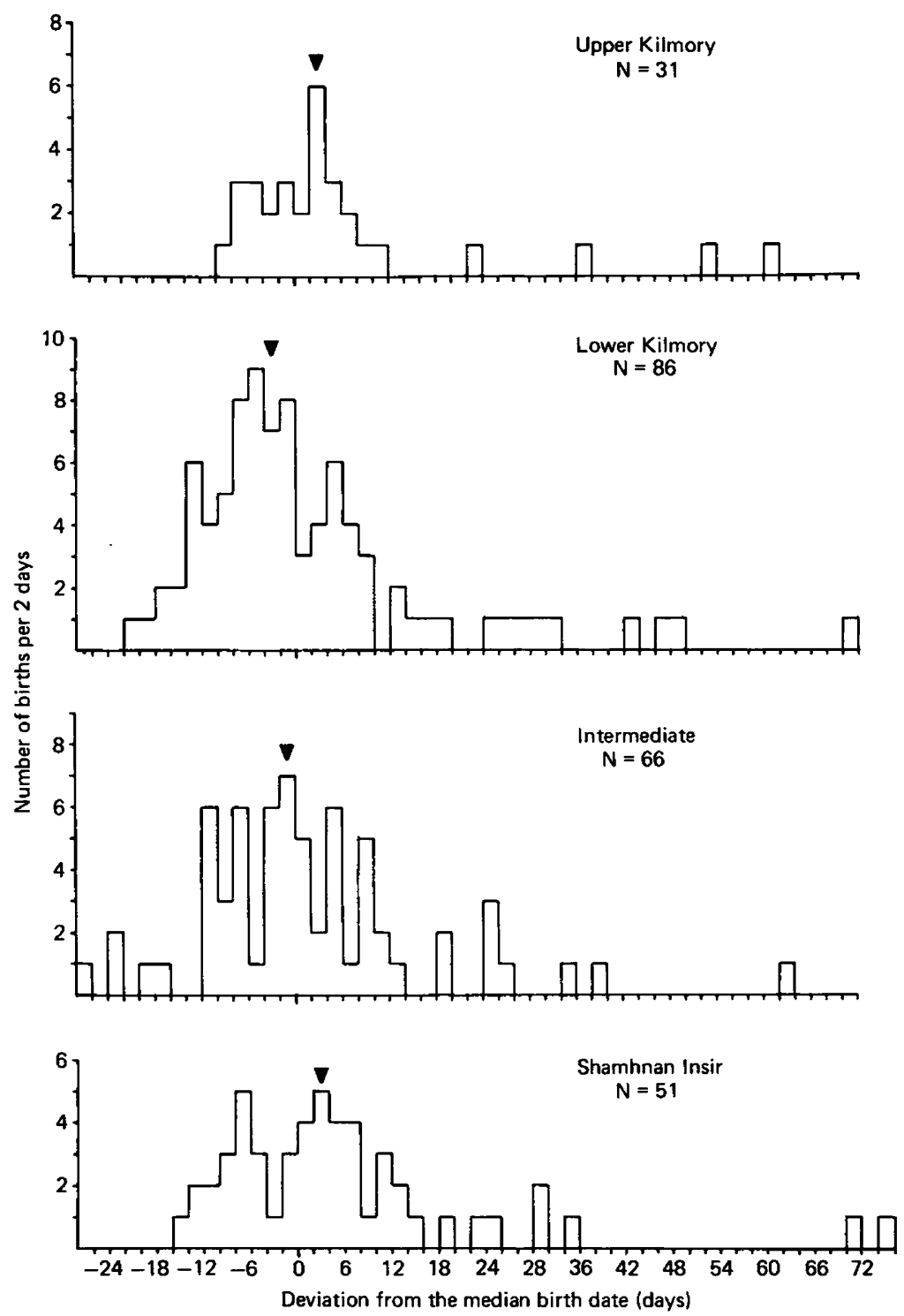

Text-fig. 2. Distribution of birth dates for red deer hinds in the four parts of the study area. The data are those for 1971-1976 and are expressed as deviations from the median birth date for each year. The overall median is indicated by the arrow.

It seems unlikely that fertility differences could be due to bias in the measurement of fertility, and the present results suggest that fertility varies according to the areas sampled. Both Lowe (1969) and Mitchell $(1971,1973)$ collected their samples from the whole island while ours were collected from a limited area only. Comparison of calf/hind ratios between different parts of the island for the periods 1957-1970 and 1970-1976 showed a tendency for calf/hind ratios to be higher in the northern block than elsewhere, perhaps because the area is comparatively sheltered and low-lying and the abundance of grassland is relatively high (Nature Conservancy Council, unpublished data).

Birth weights and birth dates were similar to those obtained in previous studies (Mitchell, 1971; Mitchell \& Lincoln, 1973; Blaxter et al., 1974), but we found no significant association between birth 
date and mother's age, and birth date was not related to birth weight as at the Glen Saugh deer farm (Blaxter et al., 1974). Our data, like those of Mitchell (1971), showed no significant relationship between calf sex ratio and the mother's age or reproductive success (see Caughley, 1971).

As found in previous studies (Mitchell, 1971; Mitchell \& Lincoln, 1973), reproductive performance also differed widely between years although our sample size was generally too small to produce significant results. In particular, fertility and birth weight were high in 1974 and low in 1975 while birth date was significantly later in 1976, showing some recovery in 1977 . These results suggest that some ecological factor (perhaps weather) affected reproductive performance in 1975. An analysis of inter-year differences in mortality on Rhum (Anderson, 1972) suggests that temperature in November -December may be important. None of the three variables we investigated was obviously related to density changes despite the rise in the number of hinds using the study area between 1971 and 1976.

The present analyses raise a number of questions which we are, as yet, unable to answer. Why does the sex of the calf influence the mother's chances of being fertile in the succeeding year? Why did the mother's reproductive status affect fertility and date of birth but not birth weight? It is hoped that an increased sample size will eventually provide the answers.

We thank Dr J. Morton Boyd, Director of the Nature Conservancy Council (Scotland), for permission to work on Rhum; Mr Michael Appleby, Mr Martin Ball, Mrs Lois Bee, Ms Janet Brooke, Mr Niall Campbell, Ms Rosemary Cockerill, Mr Peter Corkhill, Dr T. J. Fletcher, Mr Robert Gibson, the Hon. Kieran Guinness, the Hon. Erskine Guinness, Ms Marion Hall, Dr P. H. Harvey, Dr John Harwood, Dr G. A. Lincoln, Mr George MacNaughton, Mr Lewis Macrae, Dr B. Mitchell, Professor R. V. Short, F.R.S., Dr B. W. Staines, Mr Geordie Sturton, Mr Peter Wormell, and all the members of the Rhum community for their generous help over the past 5 years. The research project is funded by Grant No. GR 32292 from the Natural Environment Research Council to T.H.C.-B.

\section{References}

ANDERSON, J.E.M. (1972) Winter weather in relation to natural mortality of Rhum red deer. B.Sc. thesis, Department of Forestry and Natural Resources, Edinburgh.

Blaxter, K.L., Kay, R.N.B., Sharman, G.A.M., Cunningham, J.M.M. \& Hamilton, W.J. (1974) Farming the Red Deer. H.M.S.O., Edinburgh.

Caughley, G. (1971) Offspring sex ratio and age of parents.J. Reprod. Fert. 25, 145-147.

Caughtey, G. (1977) Analysis of Vertebrate Populations. John Wiley \& Sons, London.

Clutton-Brock, T.H. \& Guinness, F.E. (1975) The behaviour of red deer (Cervus elaphus L.) at calving time. Behaviour 55, 287-300.

Ferreira, C. (1970) Vegetation Map of Rhum. Nature Conservancy Council, Edinburgh.

Guinness, F.E., Lincoln, G.A. \& ShORT, R.V. (1971) The reproductive cycle of the female red deer. $J$. Reprod. Fert. 27, 427-438.

Guinness, F.E., Gibson, R.M. \& Clutton-Brock, T.H. (1978a) Calving times of red deer on Rhum. J.Zool., Lond. 185, 105-114.

Guinness, F.E., Clutron-Brock, T.H. \& Albon, S.D. (1978b) Factors affecting calf mortality in red deer (Cervus elaphus L.) on Rhum. J. Anim. Ecol. 47, in press.

EOMNICKI, A. (1978) Individual differences between animals and the natural regulation of their numbers. J. Anim. Ecol. 47, 461-476.
Lowe, V.P.W. (1969) Population dynamics of the red deer (Cervus elaphus L.) on Rhum. J. Anim. Ecol. $38,425-457$.

McCullough, D.R. (1971) The Tule elk, its history, behavior and ecology. Univ. Calif. Publs. Zool. 88, 1-191.

Mitchell, B. (1971) The weights of new-born to oneday-old red deer calves on Scottish moorland habitats. J. Zool., Lond. 14, 250-254.

Mitchell, B. (1973) The reproductive performance of wild Scottish red deer, Cervus elaphus L. J. Reprod. Fert., Suppl. 19, 271-285.

Mitchell, B. \& Lincoln, G.M. (1973) Conception dates in relation to age and condition in two populations of red deer in Scotland. J. Zool., Lond. 171, 141-152.

Mitchell, B., McCowan, D. \& Nicholson, I.A. (1976) Annual cycles of body weight and condition in Scottish red deer, Cervus elaphus L. J. Zool., Lond. 180, 107-127.

Mitchell, B., Staines, B.W. \& Welch, D. (1977) Ecology of Red Deer. Institute of Terrestrial Ecology, Cambridge.

SADLEIR, R.M.F.S. (1969) The Ecology of Reproduction in Wild and Domestic Mammals. Methuen \& Co. Ltd, London.

SIEGEL, S. (1956) Non-parametric Statistics for the Behavioral Sciences. McGraw Hill, Tokyo. 
SoKAl, R.R. \& RoHII, F.J. (1969) Biometry. W. H. Freeman \& Co. San Francisco.

STANES, B.W. (1978) The dynamics and performance of a declining population of Red deer (Cerous elaphus).
J.Zool., Lond. in press. $184.403-419$.

Younoson, R. (1971) Rearing red deer calves in cap? tivity. J. Wild. Mgmt 34, 467-470.

Recelved 15 March 1976 